\title{
PENINGKATAN KETERAMPILAN MAHASISWA PGSD ULM DALAM MENULIS DONGENG ANAK BERBASIS SOSIOKULTURAL MELALUI STRATEGI MENULIS TERBIMBING
}

\author{
Dessy Dwitalia Sari ${ }^{1}$ \\ ${ }^{1}$ FKIP, PGSD Universitas Lambung Mangkurat \\ email:dessy.sari@ulm.ac.id
}

Received : 17 June, 2020

Revised: 19 June, 2020

Accepted: 22 June, 2020

\begin{abstract}
ABSTRAK
Penelitian ini bertujuan untuk meningkatkan proses pembelajaran dan hasil belajar keterampilan menulis dongeng anak berbasis sosiokultural mahasiswa PGSD ULM melalui strategi menulis terbimbing. Jenis penelitian ini merupakan penelitian tindakan kelas. Desain penelitian menggunakan model Kemmis dan Mc Taggart terdiri dari tahap perencanaan, pelaksanaan, pengamatan, dan refleksi. Subyek penelitian adalah mahasiswa semester 3 berjumlah kelas E. Metode pengumpulan data dilakukan menggunakan tes, observasi, dan dokumentasi. Hasil penelitian menunjukkan strategi menulis terbimbing dapat meningkatkan keterampilan menulis dongeng anak berbasis sosiokultural. Keterampilan menulis dongeng anak berbasis sosiokultural mengalami peningkatan pada siklus I sebesar $23,4 \%$ dan pada siklus II mengalami peningkatan sebesar $27,5 \%$.
\end{abstract}

Kata Kunci: strategi, keterampilan, menulis

\section{ABSTRACT}

This study aims to improve the learning process and learning outcomes of sociocultural based folklore writing skills of PGSD ULM students through guided writing strategies. Type of research is classroom action research. The research design using the Kemmis and Mc Taggart models consists of the stages of planning, implementation, observation, and reflection. The research subjects were students in semester 3 of class E. The data collection method was carried out using tests, observations, and documentation. The results showed that guided writing strategies can improve socio-cultural children's fairy tale writing skills. Socioculturalbased children's fairytale writing skills increased in the first cycle by $23.4 \%$ and in the second cycle increased by $27.5 \%$.

Keywords: strategy, skills, writting 


\section{PENDAHULUAN}

Menulis menjadi bagian yang tidak terpisahkan dari mahasiswa selama menuntut ilmu di perguruan tinggi. Menulis sering kali dianggap sebagai kegiatan yang sulit dilakukan. Dalman (2015, hal. 3), menyatakan bahwa aktivitas menulis melibatkan unsur penulis sebagai penyampai pesan atau isi tulisan, saluran atau media tulisan dan pembaca atau audience adalah sebagai penerima pesan.

Kegiatan menulis harus didukung dengan kemahiran berbahasa, sehingga ide atau pesan yang disampaikan dapat tergambar secara jelas dan utuh. Hal ini berarti bahasa berperan penting dalam proses menulis. Ismawati \& Umaya (2012, hal. 5), berbahasa merupakan kelanjutan dari proses berpikir karenanya diperlukan bahasa dalam kehidupan seseorang untuk dapat berinteraksi dengan dunia di luar dirinya. Dengan demikian, pembelajaran menulis pada mahasiswa dititikberatkan pada keterampilan mengungkapkan ide, gagasan dan pikiran secara tertulis, serta melukiskan informasi sesuai dengan konteks dan situasi.

Pada pembelajaran menulis di Prodi PGSD terdapat kelemahan dalam aspek apresiasi sastra anak pada mata kuliah Pendidikan Bahasa Indonesia SD 2. Hal tersebut diperoleh dari hasil observasi pada perkuliahan Pendidikan Bahasa Indonesia SD 2. Mahasiswa belum mampu menuangkan ide dengan menciptakan tokoh-tokoh dalam dongeng, dan membuat alur suatu cerita dengan baik. Fakta lain yang banyak ditemukan adalah kesalahan penulisan ejaan, tanda baca, keterkaitan antar paragraf, pemilihan diksi, serta kerapihan tulisan. Keterampilan menulis dongeng anak oleh mahasiswa PGSD ULM masih rendah.

Selain bersumber dari keterbatasan mahasiswa, dipengaruhi juga oleh penggunaan strategi atau model pembelajaran yang kurang tepat. Kurangnya praktik menulis menjadi temuan berat yang harus diselesaikan. Adapun keterampilan menulis dongeng anak oleh mahasiswa PGSD ULM masih rendah, dengan nilai rata-rata. 6.5 jumlah mahasiswa 52 orang.

Sebagai calon guru Sekolah Dasar diharapkan dapan menjadi sosok yang kreatif dan aktif dalam menyampaikan suatu pesan kepada peserta didik. Fenomena lain yang ditemukan adalah dosen dalam mengajarkan keterampilan menulis kurang efektif kepada mahasiswa. Kurangnya bimbingan dalam kegiatan menulis juga berdampak pada hasil tulisan mahasiswa. 
Dosen membebaskan mahasiswa membuat tulisan tanpa memberikan acuan yang jelas. Tulisan yang dihasilkan menjadi sangat beragam dan tidak terfokus pada sastra anak. Selain itu, ketika pembelajaran mahasiswa mengalami kesulitan untuk berpikir kreatif dan menuangkan ide, gagasan, pikiran ke dalam bentuk tulisan.

Menulis adalah keterampilan yang memerlukan bimbingan, pengarahan, dan praktik latihan secara terus menerus, maka strategi yang kiranya mampu mengakomodir hal tersebut adalah dengan menggunakan strategi menulis terbimbing dengan materi menulis dongeng anak berbasis sosiokultural. Eanes Sabarun, (2008, hal. 114), mengatakan bahwa strategi menulis terbimbing adalah suatu strategi untuk mengembangkan keterampilan menulis dan menggunakan proses menulis untuk meningkatkan pengajaran. Strategi ini merupakan kerangka instruksional untuk segala bentuk tugas mengarang yang dipilih.

Pembelajaran menulis terbimbing (Guided writting lessons) haruslah berkaitan antara isi dan materi, pembelajaran dilakukan secara bertahap, guru atau dosen dalam praktiknya semakin lama semakin berkurang dalam proses pembimbingan, mahasiswa atau siswa semakin aktif selama pembelajaran berlangsung, proses bimbingan dilakukan secara kontinyu atau terus menerus dan bertahap. Dikatakan oleh Tompkins \& Hosknson (1995, hal. 330), langkah pembelajaran strategi menulis terbimbing adalah: (1) mengenalkan tentang unsur cerita/elemen, (2) menganalisis unsur cerita, (3) mengungkapkan isi cerita, dan (4) mereview sebuah cerita.

Berdasarkan latar belakang di atas, penelitian ini bertujuan agar proses pembelajaran keterampilan mahasiswa dalam menulis dongeng anak melalui strategi menulis terbimbing yang dilaksanakan bersama dosen meningkat, dan keterampilan menulis dongeng anak oleh mahasiswa mengalami peningkatan.

\section{METODE}

Subyek dalam penelitian ini adalah mahasiswa semester 3 kelas E Program Studi Pendidikan Guru Sekolah Dasar di Universitas Lambung Mangkurat. Penelitian yang dilakukan adalah Penelitian Tindakan Kelas dengan kegiatan perencanaan, tindakan, pengamatan, dan refleksi. Terdapat dua variabel dalam penelitian ini yaitu keterampilan menulis dongeng anak berbasis sosiokultural dan pembelajaran menulis melalui strategi menulis terbimbing. Instrumen yang 
digunakan untuk mengumpulkan data dalam penelitian ini menggunakan tes, catatan lapangan, pedoman pengamatan dan dokumentasi.

\section{Teknik Analisis Data}

Analisis data dalam penelitian ini digunakan untuk menggambarkan fakta yang sesuai dengan data yang diperoleh untuk mengetahui keterampilan menulis selama proses pembelajarann. Selain itu juga utuk mengetahui keaktifan siswa dalam proses belajar.

\section{Analisis Hasil Observasi (Pengamatan)}

Data yang diperoleh dari lembar observasi adalah data pengamatan terhadap pembelajaran keterampilan menulis dongeng anak yang dilakukan dosen serta data pengamatan terhadap mahasiswa dalam menulis naskah dongeng anak berbasis sosiokultural. Data observasi terhadap keterampilan menulis dongeng anak yang dilakukan dosen dipaparkan dengan deskripsi kualitatif.

\section{Analisis Keberhasilan Produk}

Keberhasilan produk diperoleh dari keberhasilan mahasiswa dalam praktik menulis dongeng anak melalui strategi menulis terbimbing. Hasil tes dianalisis secara kuantitatif. Untuk mengetahui ada atau tidaknya peningkatan menulis dongeng anak yang dilakukan oleh mahasiswa dengan membandingkan hasil tes di akhir setiap siklus. Hasil penelitian dianalisis menggunakan presentase dengan rumus dan kriteria penilaian sebagai berikut:

$$
\begin{aligned}
& \mathrm{NP}=\text { RSM } \times 100 \\
& \text { Keterangan: } \\
& \mathrm{NP} \quad=\text { Nilai persen yang dicari atau diharapkan } \\
& \mathrm{R} \quad=\text { Skor mentah yang diperoleh } \\
& \mathrm{SM} \quad=\text { Skor maksimum } \\
& 100 \quad=\text { Bilangan tetap }
\end{aligned}
$$

\section{Analisis Dokumentasi}

Data gambar foto dari siklus satu ke siklus berikutnya dipaparkan dengan deskriptif kualilatif. Gambar foto digunakan untuk melengkapi hasil observasi. 


\section{PEMBAHASAN}

Hasil penelitian ini diperoleh dari data yang sudah dikumpulkan baik dari hasil tes maupun nontes. Hasil dan pembahasan terangkum dalam tiga bagian, yaitu prasiklus, siklus I, dan siklus II. Data prasiklus diperoleh saat melakukan observasi sebelum penelitian dilaksanakan dengan mengamati proses perkuliahan Bahasa Indonesia SD 2 mengenai sastra anak.

Diketahui dari hasil prasiklus rata-rata penilaian hasil tes menulis dongeng anak hanya mendapat 67,8 selain itu dari 51 jumlah mahasiswa semester 3 kelas yang mencapai nilai tuntas berjumlah 25 mahasiswa atau sekitar $49 \%$, sedangkan 26 mahasiswa mendapat nilai dibawah rata-rata (belum tuntas). Berdasarkan hasil observasi prasiklus sebelum tindakan serta hasil penilaian prasiklus maka peneliti menyusun rencana perbaikan pembelajaran menulis dongeng anak sehingga diharapkan keterampilan menulis dongeng anak dapat meningkat.

Pada setiap siklus, dilakukan 3 kali pertemuan dengan pembahasan mengenai materi unsur-unsur dongeng, dan tata bahasa yang baik dan benar, serta cara mengembangkankerangka karangan menjadi cerita dongeng yang apik dan menarik. Setiap akhir siklus dilakukan tes menulis dongeng anak. Hasil penelitian prasiklus, siklus I, dan siklus II disajikan dalam bentuk deskripsi data kualitatif.

\section{Hasil Penelitian Siklus I}

Tindakan awal penelitian dilakukan pada siklus I dengan mengacu pada hasil observasi, wawancara dan tes awal pada pertemuan prasiklus. Strategi yang digunakan pada siklus I ini menggunakan strategi menulis terbimbing. Pada pelaksanaannya mahasiswa diberikan materi awal sebagai pedoman dalam penulisan dongeng anak, kemudian mahasiswa dibebaskan untuk membuat dongena sesuai dengan ide dan gagasan masing-masing. Dosen membimbing dan mefasilitasi mahasiswa yang mengalami kesulitan pada proses penulisan.

Hasil observasi yang dilakukan pada pertemuan pertama sampai ketiga siklus I diperoleh data bahwa mahasiswa belum banyak fokus dalam proses penulisan. Banyaknya mahasiwa yang masih bingung dalam membuat tema dan topik penulisan. Susunan kosa kata masih belum terstruktr. Beberapa mahasiswa menyusun karangan menggunakan bahasa daerah yang tidak dapat digunakan secara general. Hasil penelitian siklus I ini masih belum didapatkan perubahan yang signifikan baik dari proses pembelajaran maupun hasil tes. 


\section{Hasil Penelitian Siklus II}

Penelitian yang dilakukan pada mahasiswa PGSD ULM tentang keterampilan menulis dongeng anak siklus I belum dapat dikatakan memenuhi target. Nilai yang diperoleh masih dalam kategori cukup dan belum maksimal. Proses pembelajaran juga masih belum terlihat perubahan yang bermakna. Strategi yang diterapkan belum sepenuhnya terlaksana dengan baik. Beberapa fakta tersebut menjadi faktor untuk mengabil keputusan melakukan penelitian tindakan siklus II.

Pada siklus II, penelitian dilakukan dengan persiapan dan proses pembelajaran yang lebih matang dan terarah. Berpedoman pada kekurangan yang ditemukan pada siklus I, maka pertemuan pertama siklus II dosen memberikan bimbingan secara lebih terarah. Pembimbingan difokuskan pada penyusunan kerangka karangan, pemilihan diksi dalam setiap kalimat, serta mengarahkan pengambilan tema yang sesuai dengan usia siswa sekolah dasar. Pertemuan dua dan tiga siklus II, mahasiswa mulai menyusun tulisan secara mandiri dengan bimbinga $\mathrm{n}$ dan perbaikan dari dosen.

Pada siklus II ini peneliti tidak hanya berfokus pada hasil tulisan saja, tetapi juga proses tahapan penulisan dan bimbingan yang dilakukan untuk menghasilkan cerita dongeng yang menarik dan berbasis sosiokultural. Meningkatkan perilaku pembelajaran yang aktif, kreatif dan berpandangan luas berpengaruh pada hasil tes yang dilaksanakan.

Berdasarkan observasi yang dilakukan proses pembelajaran pada siklus II masih menerapkan cara yang sama dengan siklus I. Wawancara dan dokumentasi masih digunakan pada siklus II untuk memperkuat data hasil penelitian.

Kegiatan menulis dongeng anak mengacu pada 5 indikator penulisan yaitu: (1) penokohan/tokoh; (2) alur; (3) setting/latar; (4) diksi; dan (5) tanda baca. Pada siklus II, bimbingan difokuskan pada 5 indikator peulisan dongeng anak. Kendala yang terjadi pada siklus I sudah dapat teratasi pada siklus II ini, meskipun belum $100 \%$ mahasiswa mampu menulis dongeng anak dengan baik dan benar. Strategi bimbingan yang diberikan dinyatakan mampu memberikan perubahan proses pembelajaran menjadi lebih bermakna, dengan ditandai naiknya hasil tes yang dilakukan pada akhir siklus. Berdasarkan fakta dan data tersebut, maka siklus dihentikan. 


\section{KESIMPULAN}

Proses pembelajaran menggunakan strategi menulis terbimbing juga berdampak kepada cara menulis mahasiswa. Keterampilan menulis mahasiswa menjadi lebih baik dan sistematis dari sebelumnya. Hal ini dapat dibuktikan dari data observasi dan dokumentasi pada setiap siklus.

Keterampilan menulis dongeng anak berbasis sosiokultural oleh mahasiswa PGSD Universitas Lambung Mangkurat setelah mengikuti perkuliahan dengan menggunakan strategi menulis terbimbing mengalami peningkatan dari prasiklus hingga ke siklus II.

Pada hasil pra siklus yaitu sebelum diterapkannya strategi menulis terbimbing, menunjukkan rata-rata skor yang dicapai 67,8 atau sebesar 49\%. Pada siklus I memperoleh skor nilai rata-rata 72,6 atau 72,5\% dengan jumlah mahasiswa yang tuntas sebanyak 37 orang dari total mahasiswa 51 orang. Peningkatan skor tes dari prasiklus dengan siklus I sebesar 23,4\%. Pada siklus II rata-rata skor meningkat menjadi 87,4 dengan jumlah tuntas mencapai 100\%. Siklus II ini mengalami peningkatan sebanyak $27,5 \%$ dari siklus I.

Berdasarkan simpulan hasil penelitian, maka saran yang dapat peneliti sampaikan adalah:

1. Para pendidik agar dapat menggunakan berbagai strategi dalam proses pebelajaran, seperti halnya strategi menulis terbimbing.

2. Strategi menulis terbimbing menjadi salah satu strategi yang efektif dalam mnegajarkan keterampilan menulis disetiap jenjang pendidikan.

3. Bimbingan yang diberikan kepada mahasiswa adalah bentuk tindakan yang positif yang selaknya diberikan secara berkelanjutan dalam berbagai perkuliahan yang dilakukan.

4. Penelitian dapat dilanjutkan untuk peneliti selanjutnya dan memberikan pengalaman belajar yang dapat menumbuhkan inovasi dalam keterampilan menulis. 


\section{DAFTAR PUSTAKA}

Ausubel, David P., Joseph D. Novak, dan Hele H. (1978). Educational Psychology. New York: Holt, Rinerhard and Winston.

Dalman. (2015). Menulis Karya Ilmiah. Depok: Raja Grafindo Persada.

Fromkin, Victoria., Rodman, Robert., \& Hyams., Nina. (2014). An Intriduction to Language. Tenth Edition. Boston: Wadsworth.

Ismawati, Esti \& Umaya, Faraz. (2012). Belajar Bahasa di Kelas Awal. Yogyakarta: Ombak.

Mitchell, M. B. (2010). Learning about Ourselves through Fairy Tales: Their Psychological Value. Psychological Perspectives, 53(3), 264-279.

Purwanto. (2010). Evaluasi Hasil Belajar. Yogyakarta: Pustaka Pelajar.

Sabarun. (2008). Meningkatkan Keterampilan Menulis Paragraf dengan strategi Menulis Terbimbing (STM) Bagi Mahasiswa Semester 4 Jurusan Teknik Elektro di Universitas Muhammadiyah Malang. Jurnal Study Agama dan Masyarakat, Malang: Universitas Muhammadiyah Malang. Volume 5 No.1.

Shah P. M. (2011). Self-Efficacy in the writing of malaysian ESL learners. world applied sciences jornal 15. Innovation and pedagogy for lifelong learning.

Sugiyono. (2009). Metode penelitian pendidikan: Penelitian kuatitatif, kualitatif, dan $R \& D$. Bandung: Alfabeta.

Tomkins, G.E. \& Kenneth H. (1995). Language Arts. Content and Teaching Strategies. New Jersey: Prentice Hall, Inc. 